\title{
The hell at the heart of paradise
}

\section{Introduction: more writings from L'Hôpital Chirurgical Mobile No. 1}

Mary Borden published The Forbidden Zone in 1929, more than ten years after the armistice. ${ }^{1}$ Long before this - indeed, even before the war itself had ended - Agnes Warner's My Beloved Poilus had appeared in her home town of Saint John, New Brunswick. ${ }^{2}$ But it was one of Borden's trained nurses, Ellen La Motte, who produced the earliest memoir of L'Hôpital Chirurgical Mobile No. 1. The Backwash of War was published by Putnam's in New York in 1916. ${ }^{3}$ The book bears remarkable stylistic similarities to Borden's The Forbidden Zone. The two women almost certainly knew each other, and historian Margaret Higonnet has suggested that they observed each other closely. ${ }^{4} \mathrm{La}$ Motte refers directly to Borden as 'La Directrice' and offers her patron a dedication in the frontispiece to her book. ${ }^{5}$ By contrast, Borden (although she makes several interesting observations about trained nurses) never mentions La Motte directly. Some of The Forbidden Zone's chapters were published as journal articles long before its release as a full-length book; but the lapse of eleven years before its publication suggests that it might have been influenced by a reading of The Backwash of War. A fourth writer - Maud Mortimer - describes a hospital that bears such remarkable similarities to the field hospital described by Borden, Warner, and La Motte that it seems highly likely that she, too, is writing of L'Hôpital Chirurgical Mobile No. 1.

Agnes Warner commented: 'They call the hospital "le petit paradis des blessés” and are so glad to be sent here.' La Motte, by contrast, 
adopts a relentlessly cynical tone, and opens her book with an episode in which a man who has attempted suicide is dragged to the hospital against his will, to be saved so that he can be shot as a deserter.

\section{War's backwash}

If Mary Borden can be likened to a chameleon, her contemporary and colleague at L'Hôpital Chirurgical Mobile No. 1, Ellen La Motte, was surely more of a rhinoceros. On 3 December 1951, in an article published in the Greensburg Morning Review, a journalist reported that:

On the walls of her red frame house in Washington's old Georgetown section Miss Ellen La Motte has pictures of rhinoceroses. In her living room she has a parrot called Albert. The rhinoceros is a favourite [sic] animal of Miss La Motte. She liked the idea of its making its own way through the jungle, something she fancies she herself has done in her lifetime. ${ }^{7}$

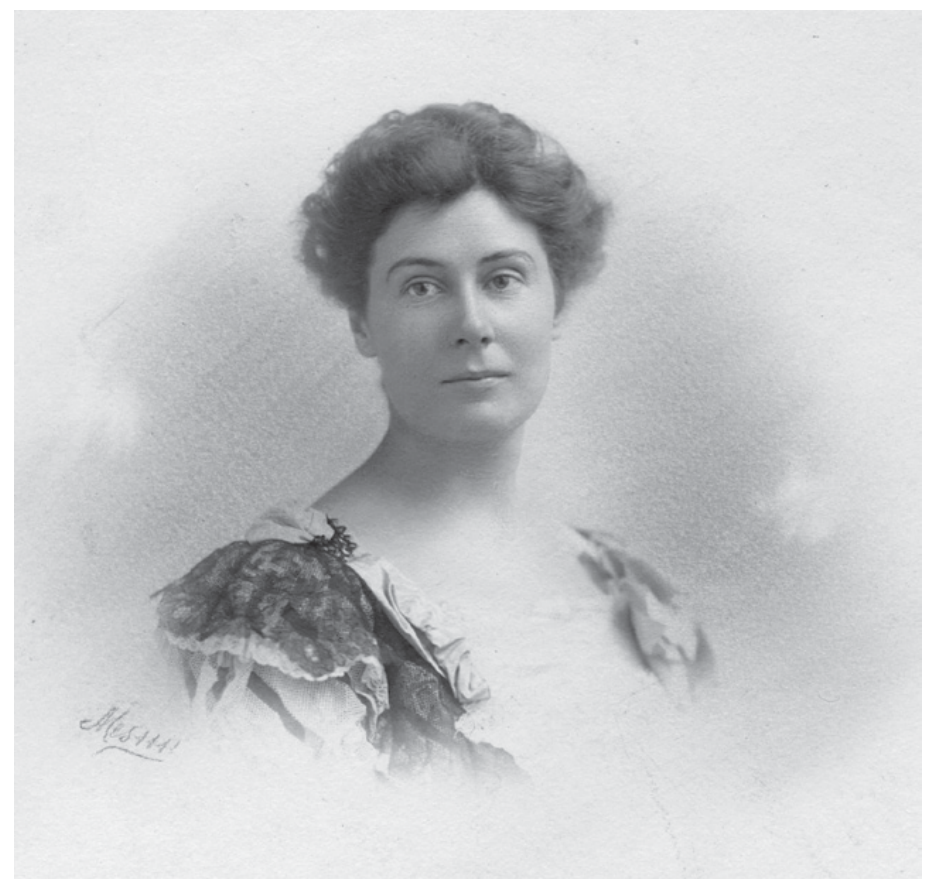

Figure 4 Portrait of Ellen La Motte 
Born in Louisville, Kentucky in 1873, La Motte was probably one of the most highly trained nurses of her generation. She entered the respected John's Hopkins Training School for Nurses in Baltimore at the turn of the century, graduating in $1902 .{ }^{8}$ Yet she appears to have been dissatisfied with her hospital experience. Almost half a century later, in October 1951, now living in Washington DC, she completed a questionnaire for May Ermer McNeill, secretary of the Johns Hopkins Hospital Nurses Alumnae Association, in which she responded tersely to a question about her experience as a student nurse: 'Nothing to evaluate. Did not like it'; and even more tersely to a similar question about her experience as a graduate nurse: 'Ditto.'

La Motte appears to have had an itinerant childhood, spending part of her time with relatives in Wilmington, Delaware, before attending a fashionable boarding school in Arlington, Virginia. ${ }^{10}$ She enjoyed a highly successful career, working as a supervising nurse at the Johns Hopkins Hospital for two years, before moving to St Luke's Hospital in St Louis, as assistant superintendent. In 1905 she turned her attention to community nursing and spent five years as a tuberculosis nurse with the Instructive Visiting Nurses Association in Baltimore. She was appointed Superintendent of the Tuberculosis Division of the Baltimore Health Department in $1910 .{ }^{11}$ But her success masked a controversial approach to tuberculosis nursing, and Keiko Sugiyama has suggested that her departure for France in 1915 was an escape from 'minority status in the controversies about the treatment of tuberculosis. ${ }^{12}$

Ellen La Motte's dispute with senior figures in the US nursing profession is revealing of her personality. It appears to have revolved around her adoption of a hard-line approach to the control of tuberculosis. Her philosophy was set down in a textbook, The Tuberculosis Nurse, which was published soon after her departure for France. In it, she advised that, 'tuberculosis is largely a disease of the poor - of those on or below the poverty line. We must further realize that there are two sorts of poor people - not only those financially handicapped and so unable to control their environment, but those who are mentally and morally poor, and lack intelligence, will-power and self-control.' ${ }^{13}$ La Motte recommended open communication with, and the careful education of, tuberculosis sufferers, ${ }^{14}$ but added that if patients did not comply with preventive measures they must be segregated 
from the rest of society. This rather harsh approach was at odds with the more overtly nurturing attitudes of nurse leaders, such as Lillian Wald and Lavinia Dock. ${ }^{15}$ La Motte also risked alienating her physician colleagues by virtually accusing them of exploiting their patients by withholding information. ${ }^{16}$ In his introduction to her book, Louis Hamman, physician in charge of the Phipps Tuberculosis Dispensary, commented diplomatically: 'one is impressed by the honesty and enthusiasm of the book, but some may wish that certain of the statements, and particularly some strictures had been a little mollified.' ${ }^{17}$

During her training at Johns Hopkins La Motte may have become acquainted with Gertrude Stein (who was, at that time, a medical student at the hospital). Stein, one of the most remarkable intellects of her time, did not complete her medical training, but went on, instead, to study psychology with William James, and then to pursue a career as a writer. She developed an extraordinary style that was later to be viewed as an important strand in the development of twentieth-century literary modernism. ${ }^{18}$ It was probably she who introduced La Motte to Mary Borden. Stein's 'salon' at the rue de Fleurus in Paris was a recognised avant-garde centre of art and literature. Although their emphases were different, Borden and La Motte wrote in similar styles, drawing upon their personal experiences to produce terse and harrowing accounts of the war. ${ }^{19}$

La Motte - a descendent of influential French Huguenots - was probably motivated, at least in part, by a desire to support her ancestral homeland. ${ }^{20}$ When she first arrived in Paris, she nursed at the American Hospital at Neuilly, finding it a profoundly unsatisfying place to work. Not only was it under-equipped and marred in its operation by an unwieldy bureaucracy, it was also over-staffed with volunteers. ${ }^{21}$ La Motte realised that the most essential and effective wartime nursing work could only be done close to the front lines. According to Stein, La Motte was 'gun-shy'. ${ }^{22}$ Nevertheless, she wanted to nurse in a field hospital, where her expertise could be of use, and, in the summer of 1915, she accepted an invitation to work for Mary Borden at the newly formed Hôpital Chirurgical Mobile No. $1 .^{23}$

In June 1915, La Motte found herself under bombardment at Dunkirk whilst en route from Paris to Rousbrugge. She decided to 'kill time' by writing an account of her experiences for the popular American journal The Atlantic Monthly. Her writing is vivid and 
immediate; she informs the reader that she is describing events as they unfold, in an attempt to calm her nerves, adding that as each shell strikes I spring back to the window, and my chair falls backwards, while the others laugh. ${ }^{24}$ Her article was published five months later. In its opening paragraphs, she focuses on how her arrival in the 'zone of the armies' made her feel that 'individual liberty was gone', adding: 'the longer one stays in the military areas, the more this sense of being a prisoner at large weighs upon one. ${ }^{25}$

La Motte's description of bombardment brings the reader close to the emotions of those trapped within Dunkirk's walls, waiting for each high-explosive shell. The day she is there, the town is steadily bombarded: approximately every forty minutes four shells fall, before the guns are left to cool. At first, watching from the balcony of her hotel, La Motte finds the bombing 'overwhelmingly interesting and exciting. ${ }^{26}$ But later that morning, an ill-advised journey into the centre of the town results in a much closer encounter with bombardment. La Motte describes how she begins to feel 'cold terror', as she realises that, while smaller shells can tear holes in buildings, 'these monster obus, dropping from the sky, crush buildings to the earth. ${ }^{27}$ As the shells begin to fall again, La Motte experiences a moment of paralysing fear, and far from 'walking slowly through the bombardment' like the nurses in Antwerp described by Sarah Macnaughtan, ${ }^{28}$ she stands bewildered:

Never for a second was there any fear of death, but an agonizing fear of the concussion, of a jaw torn off, of a nose smashed in ... In that fearful moment, there was not one intellectual faculty I could call upon. There was nothing in past experience, nothing of will-power, of judgement, of intuition, that could serve me. I was beyond and outside and apart from the accumulated experience of my lifetime. My intelligence was worthless in this moment of supreme need. Every decision would be wrong, every movement would be in the wrong direction, and it was also wrong to stand still. ${ }^{29}$

Eventually, La Motte finds shelter in the cellar of a private house. Here, she is impressed by the calm fatalism of Dunkirk's residents, and feels moved to record the striking contrast between their 'dignified acceptance' of their position in the front line of war and 'the hysterical sobbing of the London press, raving over "baby-killers" and "slayers of women"'. ${ }^{30}$ Such deliberate and open critique of British propaganda is rare in La Motte's writing. Her more usual approach is 
to confront the reader with the realities of war; this is the strategy she uses in a succession of articles for US journals, later drawn together into her book, The Backwash of War.

La Motte opens The Backwash of War with an introduction in which she makes it clear what her intentions are. She is, she informs the reader, about to relate her experiences in a French military hospital, about ten kilometres behind the front lines, in Belgium. Here 'months of boredom' are 'punctuated by moments of intense fright.' ${ }^{31}$ In the 'zone of the armies', although there may at times be 'glorious deeds of valour, courage, devotion, and nobility' there is also 'a stagnant place, ${ }^{32}$ where

much ugliness is churned up in the wake of mighty, moving forces. We are witnessing a phase in the evolution of humanity, a phase called War - and the slow, onward progress stirs up the slime in the shallows, and this is the Backwash of War. It is very ugly. There are many little lives foaming up in the backwash. They are loosened by the sweeping current, and float to the surface, detached from their environment, and one glimpses them, weak, hideous, repellent. After the war, they will consolidate again into the condition called Peace. ${ }^{33}$

La Motte's world view is an intensely bleak one: although human nature has the capacity to be good, it is also often repulsive and disgusting. She will, she says, reveal this ugly side of humankind.

The short stories that follow, drawn from La Motte's own experience at L'Hôpital Chirurgical Mobile No. 1, are powerful. They repel even as they fascinate, compelling the reader to encounter what La Motte views as the truth. Her purpose is undoubtedly pacifist, yet her writing feels like an aggressive assault on the reader's consciousness. The opening sequence to her first story, which is ironically entitled 'Heroes', begins with an attempted suicide:

When he could stand it no longer, he fired a revolver up through the roof of his mouth, but he made a mess of it. The ball tore out his left eye, and then lodged somewhere under his skull, so they bundled him, cursing and screaming, to the nearest field hospital. The journey was made in double-quick time, over rough Belgian roads. To save his life, he must reach the hospital without delay, and if he was bounced to death, jolting along at breakneck speed, it did not matter. That was understood. He was a deserter, and discipline must be maintained. Since he had failed in the job, his life must be saved, he must be nursed back to health, until he was well enough 
to be stood up against a wall and shot. This is War. Things like this also happen in peace time, but not so obviously. ${ }^{34}$

'Heroes' had first been published in August 1916 in The Atlantic Monthly. ${ }^{35}$ It is probably the most powerful of the thirteen vignettes that make up The Backwash of War. The short sentences, the staccato feel to the text, and the insistent repetition of ugly truths assault the reader, who is compelled to watch, to see, to listen. And it is this insistence on forcing the reader to confront truth that gives La Motte's writing its power.

The Backwash of War had a difficult reception. First published in the USA in the autumn of 1916, it was suppressed by the censor in 1918, several months after America's entry into the war. ${ }^{36}$ Its publication had been permitted neither in Britain nor in France. In a new introduction, written for a 1934 reprint of her book, La Motte describes how she had only realised that the book had been banned in the USA when an issue of the journal The Liberator appeared with a recommendation for The Backwash of War inked out. ${ }^{37}$ In the mid-1930s, as another European war seemed imminent, La Motte warned 'there can be no war without this backwash. ${ }^{38}$ Her book was rediscovered in the late twentieth century by feminist historians and critical theorists, excited by its uncompromising attitude to warfare and the beauty of its literary style. ${ }^{39}$

For Ellen La Motte, L'Hôpital Chirurgical Mobile No. 1 - which others had named 'le petit paradis des blessés' - was a place of horror and degradation. The importance of perspective and the power of interpretation become clear when one compares the narratives of Agnes Warner, for whom every French soldier is a hero; Mary Borden, who seems to be searching for a spiritual reality beyond individual suffering; and Ellen La Motte, who sees only human weakness and a monumental waste. In her article 'A Joy Ride', La Motte refers to Borden as 'the Directrice, who is my friend', ${ }^{40}$ and she dedicates The Backwash of War to "Mary Borden-Turner[,] "The Little Boss" to whom I owe my experiences in the zone of the armies'; ${ }^{41}$ but in her fifth chapter, 'A Belgian Civilian', she seems to satirise the way in which Borden scolds a Belgian mother for not remaining with her dying child, when Borden herself has left three children at home in England to pursue the life and adventures of the Front. ${ }^{42}$ 
One of the truths that La Motte is anxious to convey is that, in fact, life in the zone of the armies is not exciting and adventurous:

At times, at the front, it gets frightfully dull. When there is an attack and in consequence, plenty of work to do, it is all right in a field hospital. But when there are no attacks, when there are no new patients and all the old ones become convalescent, when there is practically no work, it becomes insupportable. Nothing but the green hedge on all sides of us, shutting us into ourselves, into our little, gossiping enclosure, with no newspapers, with no aeroplane to fly overhead, with nothing to do but walk down to the little pond and sail boats. ${ }^{43}$

In 'A Joy Ride', La Motte recounts how, at one time of such maddening boredom, her 'friend', the 'Directrice', gives her a laissez passer permitting her to take a trip with a Canadian colleague who is going to look for her nephew stationed at a rest camp near Poperinghe. The narrative that unfolds is both poignant and humorous - and very different from the harsh realities of The Backwash of War. La Motte is frank about her fear, inviting the reader to laugh not only at her two companions - an eccentric English chauffeur and a Canadian nurse who insists on going too close to the front lines - but also at herself: the gun-shy American who is searching for a lamb to bring back to the hospital as a pet. She openly confesses: 'I am not naturally what one would call brave, and since last summer, after our fourteen-hour bombardment in Dunkirk, the sight of a shelled town makes me feel quite sick. ${ }^{34}$

As the trio pass the observation balloons that mark the proximity of the front lines, and turn down a dirt track towards the Canadian camp, La Motte's anxiety increases. They pass horses with rope fringes over their eyes to protect them from shrapnel, and drive through a camp, in which Canadian troops are living in primitive 'conical wooden huts' and 'shacks' - 'just like animal pens, in which animals wait to be slaughtered. ${ }^{45}$ Suddenly, several shells burst in a field near to the road along which they are travelling, and the three begin to argue about whether to go on:

MacAlister wanted to see Donald. I had no wish whatever to see Donald, especially under these circumstance ... 'Go back quick!' I commanded. 'Can't you see they're shelling the road?' 'Eh?' said Williamson; while MacAlister kept repeating, 'I want to see Donald.' Between that slow-witted parson-chauffeur and that devoted girl, I got exasperated. I hate shells and am desperately afraid of them. It is so refreshing to admit the truth. ${ }^{46}$ 
At this point, La Motte gets out of the car, telling the others to drive on without her, and stands in a field in Flanders, 'surrounded by half-a-dozen grinning Canadian soldiers' - a situation that she finds 'a little unusual. ${ }^{47}$ Unfortunately, she is the one who is subjected to further danger - from anti-aircraft fire as a Taube flies overhead. She takes refuge in a 'flimsy' shelter, in which she is offered a very British-Canadian afternoon tea and a shell-casing to take home as a souvenir, while her colleague continues on her journey, successfully locating 'a grateful, dirty little nephew ... overjoyed to see his aunt. ${ }^{48}$ La Motte's writing offers a satirical insight into the irrationality of war. The identity of the Canadian nurse who was searching for her nephew is unknown, but on 28 August 1916, Canadian nurse Agnes Warner wrote home to her family: 'I have met our boy B - at his rest camp not very far from here. It was a joy to find him looking so well, and big and brown. ${ }^{39}$ Agnes Warner's nephew, Bayard Coster, was serving with the Canadian forces on the Ypres front.$^{50}$ It is tempting to wonder whether he was the 'Donald' of La Motte's story, and Warner herself 'that devoted girl', 'MacAlister'. But humour - even of the self-effacing variety - is rare in La Motte's writings.

La Motte was based at Borden's field hospital in Rousbrugge for over a year, from summer 1915 to autumn 1916. Towards the end of 1916, with The Backwash of War just published, she escaped the 'zone of the armies' and chose to put thousands of miles between herself and war-torn Europe, travelling to China with longstanding friend and companion Emily Chadbourne, and remaining there for two years, visiting Japan, French Indo-China, Siam, and the Straits Settlements. She spent much of her time writing and campaigning against the exploitation of colonised people, and most particularly against the opium trade. ${ }^{51}$ For her efforts, she was awarded the Lun Tse Hsu Memorial Medal by the Chinese Nationalist Government, and the Order of Merit by the Japanese Red Cross. ${ }^{52}$ Keiko Sugiyama has commented on how La Motte exposed the hypocrisy of western men and women who, 'under the banner of civilization and Christianity, were taking advantage of the natives and victimizing them. ${ }^{53}$ La Motte does, nevertheless, still portray 'native' people as stereotypically uncivilised, just as she portrays the suffering French poilu as stereotypically weak and self-indulgent, and the American immigrant tuberculosis patient as ignorant and wilful. Her attack 
on western imperialism was highly unusual for her time, but even more unusual was her attack on the weakness and immorality of the western male. ${ }^{54}$

La Motte's efforts to fight the opium trade also took her to London, where she lived for twenty years, travelling to Geneva for anti-opium meetings of the League of Nations. ${ }^{55}$ She continued to write extensively for journals and magazines. ${ }^{56}$ One of her more whimsical pieces, 'A Desert Owl', relates the story of an elderly lady living in a garret in Westminster, who purchases a desert owl, and accidentally takes home the wrong box - containing two wild exotic birds. As always, her piece shows the slightly contemptible side of human nature; yet it is also gentle and humorous, evocative of London life in the late 1920s. ${ }^{57}$

Towards the end of her life, in her interview for the Greensburg Morning Review, La Motte observed that during the Great Depression she had moved to Washington 'to get on as best she could'. She had bought and 'fixed up' old Georgetown houses, commenting that she could get them 'awfully cheap'. It was clear that, by 1951, La Motte was 'getting on' rather well. She commented to her interviewer that 'Albert [her parrot], my friends and the stock market keep me interested.' She died - no doubt, still interested - ten years later in $1961 . .^{58}$

Not all of La Motte's writings are hard-hitting exposés or satirical commentaries on the double standards of imperialism. One of her short stories - 'Under a Wine Glass' - tells the strange and whimsical tale of a talented man who has lost his creativity and his sense of self. In it La Motte asks the question: 'Do you think people ever recover themselves? When the precious thing in them, the spirit of them, has been overlaid and overlaid, covered deep with artificial layers?. ${ }^{59}$ For La Motte, it seems, her own sense of self was most intact - her spirit most free - when she had a mission to fulfil. But her clarity of expression was twinned with a sharpness of tone that exposed her to criticism and censure. Much of her writing is biting in its critique of the destructiveness of human society - as if she felt that any tone of conciliation would have compromised the truth of her message.

\section{Maud Mortimer: witnessing nursing}

When Maud Mortimer arrived at an unnamed field hospital in Flanders, she commented on its isolation. Within eight kilometres of 
the front-line trenches, and hence almost in the thick of the 'action', the field hospital was nevertheless so closed - the passage through its perimeter hedge so restricted in either direction - that its inhabitants knew less about the progress of the war than their relatives at home. Their busyness and their isolation were such that any war news that reached them was both delayed and distorted. ${ }^{60}$

The hospital consisted of 'sixteen wooden shacks', supplemented by tents, of which eight were wards, caring for about 140 patients in total. There was an operating room, also containing a 'radiographic cabinet'; a pharmacy; a salle d'attente, or reception room; a wash-house and linen room; and staff quarters. Mortimer adds that 'all the shacks and tents are connected by narrow walks or trottoirs which thread quite picturesquely back and forth across our muddy enclosure'. In her own small corner of the nurses' accommodation hut, 'everything blows, creaks, and flaps together. One feels much as a spider might in a tight crevice of bark with leaves for curtains. ${ }^{61}$

One of Mortimer's most compelling pen-portraits is of the Canadian-trained nurse who loves night duty and who has given herself the nickname 'The Night Hawk':

The Night Hawk loves poetry and quiet. She is Canadian and of the gold one bends in one's hands, out of which primitive peoples fashion their ornaments and their gods. She is all disinterestedness, all devotion and self-forgetfulness; a thoroughly trained nurse with a heart that never loses the freshness of its sympathy nor its willingness to be spent in the service of these men whose pluck is so amazing, whose rare lack of it, so pitiful. I have the happiest time in the world flitting through the night at her heels. ${ }^{62}$

A similar account of the night nurse 'flitting' into hutted wards carrying a lantern finds its way into Borden's The Forbidden Zone. The white-clad nurse moves silently across the hospital compound, carrying a glowing lantern. She encounters and fights pain - but this is a losing battle. She enters the hut reserved for gas gangrene cases. 'Pain is lying in there waiting for her', remarks Borden: 'It is holding the damp greenish bodies of the gangrene cases in her arms. ${ }^{63} \mathrm{In}$ Mortimer's account:

We carry our lanterns flickering over mud and snow and put them down at the door of each ward we visit ... While on her rounds she glides through darkened ward after darkened ward. Death - mysterious, spasmodic breathing-out of life which our instinct so curiously shrinks from - is here, 
is there, is everywhere. The beautifying touch of his obliterating finger disarms her fear. It is not so with pain, in whose wry, haunted environment is neither life nor death, but a grimly barriered and bounded No Man's Land where the bravest lose their bearings. ${ }^{64}$

Not only are these writers' descriptions strikingly similar; the detail of their narratives corresponds as well. At L'Hôpital Chirurgical Mobile No. 1, the same events may be recounted by two or three consummate story-tellers from totally different perspectives. Ellen La Motte's 'At the Telephone' offers a stark and bleak insight into the death of a young telephone operator who dies during surgery. ${ }^{65}$ Maud Mortimer recounts a similar story of a death from typhoid:

For six lagging weeks the sympathy and science of the hospital clung to the chance of saving him ... But death held on hungrily to him. In his delirium he was back in the trenches again, the receiver in his hand, feverishly active as message after message reached him and had to be sent on.

Suddenly his excitement grew. He was in the fury of bursting shells ... The pause was strained with the agony of attention. Then the muscles relaxed into a creeping smile and the lips moved again:

'Ah, ça y est, maintenant. Le bon Dieu est à l'appareil.'

The boy was dead. ${ }^{66}$

On her return to her hometown of Saint John, New Brunswick at the end of the war, Agnes Warner inspired her audience by recounting, as part of a public lecture, the story of 'a boy of nineteen who died of typhoid. He was delirious and thought he was at his telephone in the field. He gave orders all day, but at last turned to the Sister with a smile and said, "It's alright now. It is God at the telephone." '67

Borden, La Motte, and Mortimer all recount stories of the famous 'Bataillon d'Afrique', France's punishment battalion for convicted criminals.$^{68}$ Mortimer writes of 'one of the pets of the hospital and the pride of the doctors - not because of any show of health he made, poor lamb, but because he was still alive after all they had been allowed to do to him, and out of gratitude to him for all they thought they had learned to do against another time. ${ }^{69}$ She describes the patient's fate:

Our Le Groux then, 'Light Breeze' or 'Joyous One' - a bullet through the spleen and kidney, half-flayed, with stomach, liver, and part of his intestines laid impudically [sic] bare, drains in the abdominal cavity and in his back was one of the pets of the hospital and of the medical staff. If the doctors 
cherished him and cherished themselves in him, he no less cherished the doctors ... And not only did he adore his doctor, but he also adored his faithful friend the nurse - his nurse, the Night Hawk - to whom alone, by virtue of her skill and devotion, was entrusted the ceremony of his terrible dressings, and whose care came nearer to a true mother's than anything this boy had ever known. ${ }^{70}$

As Le Groux died, 'he stretched out his hands to his nurse who folded him in her arms, her hot tears falling on the white face. Twenty minutes later the general arrived to award Le Groux a medal, only to be told that the patient had died. Mortimer describes how, 'without a word, his head bent, the General turned and left the ward, two little unopened boxes in his hand, his sheathed sword hanging impotently at his side. ${ }^{71}$

In La Motte's version of a similar (or, perhaps, the same) event, the 'Directrice' (Borden), who wants to enhance the reputation of her hospital, is seen as, effectively, conspiring with a surgeon, 'who was bent on making a reputation for himself', to prolong the man's life, even though he is in agony and there is no hope of a cure. ${ }^{72}$ Yet, it is also the 'Directrice' who notices the man's courage in the face of such treatment and campaigns to have him decorated with the highest French military honour: the Croix de Guerre. The general is sceptical and delays for so long that he arrives too late. We are told that the patient 'held on as long as he could', but 'died, finally, after a long pull, just twenty minutes before the General arrived with his medals. ${ }^{73}$

The differences in emphasis between the narratives is striking. In Mortimer's version, the focus is on the importance of the relationship between the patient and his doctors and nurses. The clinicians really believe they may have a chance of saving the patient. And when the general arrives too late with his medals, he is despondent. In La Motte's recounting of the same (or a similar) story, the doctors are merely cynical scientists who experiment on their patient for their own ends; and the general arrives too late because it takes the hospital staff so long to convince him that a member of the Bataillon d'Afrique deserves to be decorated. ${ }^{74}$

A similar - possibly the same - patient appears in Agnes Warner's My Beloved Poilus, where he is referred to as 'Le Roux', a name remarkably similar to Mortimer's 'Le Groux'. La Motte's description is cynical, Mortimer's emotional. Warner's is characteristically matter-of-fact: 
January 16,1916 ... Le Roux, the boy who has been here so long and who has been so terribly ill, died on Tuesday. I had great hopes of him up till the last day. Half an hour after he died the General came up to decorate him. I hope they will send the medals to his people, it seems hard that they should have been just too late to give them to him. ${ }^{75}$

In spite of its apparent casualness, Warner's writing is pervaded by affection for her young patient. She describes how she attended his funeral the next day, adding: 'the ward seems very empty without Le Roux, but I am glad that the poor boy is at rest for he has suffered so long. And at this point - one of the few in a long series of letters Warner betrays her own despair: 'I am beginning to think that death is the only good thing that can come to many of us.' ${ }^{76}$

Another story of death in LHôpital Chirurgical Mobile No. 1 relates to a patient who expires in the moment he is decorated by the general. Mortimer's account is deliberately poignant:

The sound of rapid footsteps comes down the long ward. The General stands at the foot of the bed. Lamplight glints on his drawn sword and on the Croix de Guerre hanging from the ribbon which he holds in his hand.

'In the name of the Republic - to you, Jean Magnard' - familiar words and oft repeated in these shacks anchored too near the breaking end of the turbulent waves of human strife not to catch the spindrift of their shattered endeavour - 'In the name of the Republic ...' The erect old soldier leans forward, gently pushes back the damp wisps of hair and kisses the dying man. Then with a hand on one of the relaxed cold ones he murmurs, 'Merci, l'ami'.77

In La Motte's version of the same - or a similar - story, the patient, who dreads death, accepts that he is dying only after the general awards him his medal: 'We all knew what it meant. So did the man. When he got the medal, he knew too. He knew there wasn't any hope. I held the medal before him, after the General had gone, in its red plush case. It looked cheap, somehow. The exchange didn't seem even. He pushed it aside with a contemptuous hand sweep, a disgusted shrug. ${ }^{78}$ For La Motte, the general is merely a symbol of the harsh regime that sends men to their deaths, according them the empty, meaningless trappings of a spurious heroism.

Both La Motte and Mortimer also tell the story of a patient who dies alone while two orderlies neglect him. In Mortimer's version, we hear that 'one of the night nurses is still up and wishes to remain with 
him through the luncheon hour. But the nurse of Salle I will not hear of it ... When his nurse comes back from her midday rest, Methurin lies dead, alone. The orderlies are playing cards in the pantry. ${ }^{79} \mathrm{La}$ Motte's version is altogether harsher: 'After a short time [the nurse] came back from lunch, and hurried to see Rochard, hurried behind the flamboyant, red, cheerful screens that shut him off from the rest of the ward. Rochard was dead. At the other end of the ward sat the two orderlies, drinking wine. ${ }^{30}$

Maud Mortimer describes an interesting character at her anonymous French field hospital - a character to whom she gives the nickname 'Organization' - a fascinating American nurse who appears to be using her experience in the hospital to collect data that can be used to formulate some truth about the war:

She is almost cubistic in her dire simplifications. When she is not harassed by the tortuous complexities of other people's minds - of latin minds in particular - she has the pleasantest ways and a witty good-fellowship which plays seductively over her relentless absolutism. She adores uniformity and in all that does not touch America, she is pacifist and neutral to the backbone, though not without a weakness for politics. A fully trained and excellent nurse, she yet has done with nursing. She is not here now to probe physical weakness but to cut deeper - for the purification of art and sentiment - down to the unquestionable depravity of the human heart. ${ }^{81}$

'Organization' believes that 'there is nothing so simple as truth and that it is always ugly. ${ }^{82}$ She seems to be using the hospital quite deliberately as a field of enquiry, and Mortimer employs the metaphor of the 'vacuum cleaner' to illustrate the way in which she 'makes one buzzing round, then settles down to choose from her bag. ${ }^{83}$ 'Organization' comes across to the reader of $A$ Green Tent in Flanders, as a detached spectator who 'turns and turns the chewing gum of her inquiry, ${ }^{34}$ rather than engaging deeply in the life of the hospital. When she leaves, 'her attaché case bulges with the documentary evidence of the obliquity of human nature especially as observed under torture in a field hospital. ${ }^{85}$ Maud Mortimer's book was published in 1918, more than a year after La Motte's. In the character of 'Organization', Mortimer may be painting a carefully anonymised portrait of Ellen La Motte: turning a soft irony against the soft ironist herself, producing a mysterious message whose code could only be broken by those who had been present at L'Hôpital Chirurgical Mobile No. 1. 


\section{Conclusion: the power of interpretation}

In the small world of the field hospital, a number of nurses were caring for the same patients, observing the same events, and yet experiencing and writing about them in very different ways. Was Warner the nurse who begged a patient to eat and who took him in her arms as he died, only to describe his fate in such gently sympathetic, yet matter of fact, terms to her mother? Or was she, herself, observing one of her Canadian colleagues, of whom she later writes: 'May 3, 1916 ... The two Canadian nurses are a joy to work with, for they have had splendid training and are the kind that will go till they drop. ${ }^{86}$ And was the dying patient 'Le Roux' the same man as Mortimer's 'Le Groux', and La Motte's anonymous patient who dies 'after a long pull'?

These authors' visions of their patients are very different. For La Motte, they are 'weak, hideous, repellent. ${ }^{37}$ For Mortimer, they are suffering human beings to be pitied. For Warner and Borden, they are admirable men who have been stripped of their identities by modern warfare, and yet are able to behave with the utmost courtesy and patience. Borden describes the patients who are carried into the reception hut of her field hospital on the Somme: 'They were all so courteous voiced, using such beautiful phrases, as if they were in my drawing room. They apologized gravely in their exhaustion for the dirt, the blood, the ugly wounds. ${ }^{38}$

A woman such as Agnes Warner - infused with patriotic fervour, and steeped in the values of her own time - provides a vivid illustration of the power of a pervasive imperialist ideology. The perspectives she and women like her took with them into the First World War paralleled the perspectives of combatants, whose consciously heroic willingness to go 'over the top' has astounded later generations. For Warner's close colleagues and associates, American volunteer nurses Mary Borden and Maud Mortimer, the courage and endurance of such women were both an inspiration and an education. They extolled the healing work of the professional nurse; yet they also recognised the destructiveness of the ideological forces that made her work so necessary. Agnes Warner herself never questioned the authority that drew her patients into the most destructive war that had ever been fought. She merely poured her compassion and expertise into the repair of her damaged 'poilus', and her thoughts and feelings into her letters home. 
Another member of L'Hôpital Chirurgical Mobile No. 1 wrote with the deliberate intention of destroying the false heroic myths of the First World War and revealing what she saw as its squalid and horrific truths. ${ }^{89}$ Ellen La Motte, one of the most biting and cynical of wartime writers, was a professional nurse, who had undergone additional training and experience as a tuberculosis specialist - one of the most dangerous occupations of the early twentieth century - and who was later to travel to China as a campaigner against the opium trade. ${ }^{90}$ She was clearly not afraid of danger; yet she was referred to by Gertrude Stein as 'gun-shy' and wrote with self-denigrating wit of her encounters with bombardment.

Four nurses observed the work of one small hospital - L'Hôpital Chirurgical Mobile No. 1 - and spoke with four very different voices. Maud Mortimer's narrative was, perhaps, the most complete. In her $A$ Green Tent in Flanders, characters are given pseudonyms, yet events are recorded vividly. Mortimer herself was not a trained nurse but, in common with that of many volunteers, her writing is redolent with a sense of her fascination for nursing work, and admiration for those who could do it well and with compassion. Her heroine was the 'Night Hawk', an unnamed Canadian nurse at whose light heels she 'flitted' through the dense darkness of the field hospital.

\section{Notes}

1 Mary Borden, The Forbidden Zone (London: William Heinemann, 1929).

2 Anon., My Beloved Poilus (Saint John, NB: Barnes, 1917).

3 Ellen N. La Motte, The Backwash of War: The Human Wreckage of the Battlefield as Witnessed by an American Hospital Nurse (New York: G. P. Putnam's Sons and The Knickerbocker Press, 1916).

4 Margaret Higonnet, Nurses at the Front: Writing the Wounds of the Great War (Boston, MA: Northeastern University Press, 2001): xvii-xx.

5 La Motte, The Backwash of War: frontispiece.

6 Anon., My Beloved Poilus: 118.

7 Transcript of an article taken from the Greensburg Morning Review, Pennsylvania (3 December 1951), Ellen La Motte, biographical file, The Alan Mason Chesney Medical Archives, The Johns Hopkins Medical Institutions, Baltimore, Maryland, USA.

8 Shortly after graduation, La Motte became a member of the Johns Hopkins Nurses Alumnae. See frequent references to her work for the Alumnae 
Committee in: Anon., The Johns Hopkins Nurses Alumnae Magazine, 7 (1908), passim.

9 Ellen La Motte, biographical file, The Alan Mason Chesney Medical Archives, The Johns Hopkins Medical Institutions, Baltimore, Maryland, USA, questionnaire.

10 La Motte, biographical file.

11 La Motte, biographical file.

12 Keiko Sugiyama, 'Ellen La Motte, 1873-1961: Gender and Race in Nursing, The Japanese Journal of American Studies, 17 (2006): 129-141 (133).

13 Ellen N. La Motte, The Tuberculosis Nurse: Her Function and Her Qualifications. A Handbook for Practical Workers in the Tuberculosis Campaign. By Ellen N. La Motte, R.N., Graduate of Johns Hopkins Hospital; Former Nurse-in-Chief of the Tuberculosis Division, Health Department of Baltimore, introduction by Louis Hamman, M.D., Physician in Charge, Phipps Tuberculosis Dispensary, Johns Hopkins University (New York and London: G.P. Putnam's Sons and The Knickerbocker Press, 1915): 3.

14 La Motte, The Tuberculosis Nurse: 285.

15 Sugiyama, 'Ellen La Motte': 131-3. On the late-nineteenth-century disputes over the control of tuberculosis, see also: Jessica M. Robbins, 'Class Struggles in the Tubercular World: Nurses, Patients, and Physicians, 1903-1915, Bulletin of the History of Medicine, 71.3 (1997): 412-34.

16 La Motte, The Tuberculosis Nurse: 103.

17 La Motte, The Tuberculosis Nurse: introduction.

18 Higonnet, Nurses at the Front; Margaret Higonnet, 'Authenticity and Art in Trauma Narratives of World War I', Modernism/Modernity, 9.1 (2002): 91-107; Ariela Freedman, 'Mary Borden's Forbidden Zone: Women's Writing from No-Man's Land' Modernism/Modernity, 9.1 (2002): 109-24.

19 Gertrude Stein writes of her meetings with Ellen La Motte and Mary Borden in her autobiographical account: Gertrude Stein, The Autobiography of Alice B. Toklas (London: Penguin, 2001 [1933]): 172, 184-5. On the deliberately challenging nature of Stein's writing, see: Sidonie Smith and Julia Watson, Reading Autobiography: A Guide for Interpreting Life Narratives (Minneapolis: University of Minnesota Press, 2010): 36. On the nature of early-twentieth-century literary modernism, see: Lawrence Rainey, Modernism: An Anthology (Oxford: Blackwell Publishing, 2005): xix-xxix; Howard Booth and Nigel Rigby (eds), Modernism and Empire (Manchester: Manchester University Press, 2000). On the links between modernism and the First World War, see: Allyson Booth, Postcards from the Trenches: Negotiating the Space between Modernism and the First World War (Oxford: Oxford University Press, 1996); Trudi Tate, Modernism, History and the First World War (Manchester: Manchester University Press, 1998).

20 She was a member of the Huguenot Society of America: La Motte, biographical file. 
21 Ellen N. La Motte, 'An American Nurse in Paris', The Survey, 34 (10 July 1915): 333-6.

22 Stein, The Autobiography of Alice B. Toklas: 184.

23 On La Motte's arrival in Paris, see: Higonnet, Nurses at the Front: xi; Angela Smith, Women's Writings of the First World War: An Anthology (Manchester: Manchester University Press, 2000): 330.

24 Ellen La Motte, 'Under Shell-Fire at Dunkirk', The Atlantic Monthly, 116 (November 1915): 692-700 (700).

25 La Motte, 'Under Shell-Fire': 692.

26 La Motte, 'Under Shell-Fire': 695.

27 La Motte, 'Under Shell-Fire’: 697.

28 Sarah Macnaughtan, A Woman's Diary of the War (London: Thomas Nelson and Sons, 1915).

29 La Motte, 'Under Shell-Fire': 698.

30 La Motte, 'Under Shell-Fire': 699.

31 La Motte, The Backwash of War: v.

32 La Motte, The Backwash of War: v.

33 La Motte, The Backwash of War: vi.

34 La Motte, The Backwash of War: 3-4.

35 Ellen N. La Motte, 'Heroes', The Atlantic Monthly, 118 (August 1916): 208-10.

36 On the suppression of The Backwash of War, see: Angela Smith, The Second Battlefield: Women, Modernism and the First World War (Manchester: Manchester University Press, 2000): 77-8; Claire Tylee, The Great War and Women's Consciousness: Images of Militarism and Womanhood in Women's Writings, 1914-64 (Houndmills and London: Macmillan, 1990): 94.

37 Ellen N. La Motte, The Backwash of War: The Human Wreckage of the Battlefield as Witnessed by An American Hospital Nurse (New York: G. P. Putnam's Sons, 1934), introduction.

38 La Motte, The Backwash of War (1934): introduction.

39 Smith, The Second Battlefield; Higonnet, Nurses at the Front; Higonnet, 'Authenticity and Art': 91-107; Freedman, 'Mary Borden's Forbidden Zone': 109-24.

40 Ellen N. La Motte, 'A Joy Ride', The Atlantic Monthly, 118 (October 1916): 481-90 (481).

41 La Motte, The Backwash of War (1916): frontispiece dedication.

42 La Motte, The Backwash of War (1916): 70.

43 La Motte, 'A Joy Ride': 481.

44 La Motte, 'A Joy Ride': 484.

45 La Motte, 'A Joy Ride': 485.

46 La Motte, 'A Joy Ride': 486.

47 La Motte, 'A Joy Ride': 486.

48 La Motte, 'A Joy Ride': 489. 
49 Anon., My Beloved Poilus: 111.

50 I am indebted to Shawna Quinn for drawing my attention to the parallels between Warner's letter and La Motte's narrative, and also for sending me, amongst many other sources, an electronic link to Bayard Coster's attestation papers: www.collectionscanada.gc.ca/databases/cef/001042-119.01-e. php?7id_nbr-118774\&interval-20\&\&PHPSESSID-c7db3k1k2va 2 d63c6e9hiek717 (accessed June 2011).

51 While in Asia and then later in London, La Motte wrote extensively on the latter topic. See, for example: Ellen N. La Motte, Civilization: Tales of the Orient (New York: Books for Libraries Press, 1919); Peking Dust (New York: Century, 1919); The Opium Monopoly (New York: Macmillan, 1920); The Ethics of Opium (New York: Century, 1924); 'Snuffs and Butters' and Other Stories (New York: Century, 1925); Opium at Geneva; or, How the Opium Problem Is Handled by the League of Nations (New York: The Nation, 1929). For a comment on La Motte's work in Asia, see: Sugiyama, 'Ellen La Motte', 135-8.

52 La Motte, biographical file.

53 Sugiyama, 'Ellen La Motte': 136.

54 Sugiyama, 'Ellen La Motte': 129-41.

55 La Motte, biographical file, questionnaire.

56 La Motte herself commented, in 1951, that her publications were 'too numerous to recall', and included contributions to Harper's Magazine, The Atlantic Monthly, The Nation, and Foreign Affairs: La Motte, biographical file.

57 Ellen N. La Motte, 'A Desert Owl', The Atlantic Monthly (January 1927): 81-6, available in La Motte, biographical file. In the same collection, see also: Ellen N. La Motte, 'The Three Widows: The True Story of an International Crisis', Harper's Magazine (March 1931): 428-35.

58 Sugiyama, 'Ellen La Motte': 129-41.

59 Ellen N. La Motte, 'Under a Wine Glass', The Century Magazine (December 1918): 150-4.

60 Maud Mortimer, A Green Tent in Flanders (New York: Doubleday, Page, 1918): 49.

61 Mortimer, A Green Tent in Flanders: 57-8.

62 Mortimer, A Green Tent in Flanders: 165.

63 Borden, The Forbidden Zone: 59.

64 Mortimer, A Green Tent in Flanders: 167-8.

65 La Motte, The Backwash of War (1916): 159-64.

66 Mortimer, A Green Tent in Flanders: 76-7.

67 This quotation appears in a local New Brunswick daily newspaper: Anon., 'Miss Warner Gave Splendid Lecture', Saint John Standard (11 April 1919). See also another account of the same lecture: Anon., 'War's Lessons Should Not Soon Be Forgotten: Miss Warner Tells New Phases of Her Work in France, Daily Telegraph (11 April 1919): 3, available at Saint John Archives, New Brunswick, Canada. 
68 Borden's narrative, 'Enfant de malheur', focuses on a relationship between a disturbed - almost demonic - patient, his staid British nurse, and the French Catholic priest who gives him the last rites: Borden, The Forbidden Zone: 66-92.

69 Mortimer, A Green Tent in Flanders: 146.

70 Mortimer, A Green Tent in Flanders: 147-51.

71 Mortimer, A Green Tent in Flanders: 153.

72 La Motte, The Backwash of War (1916): 168.

73 La Motte, The Backwash of War (1916): 178.

74 The details in these two narrations of the same story are remarkably similar - even to the point that each states that the general arrived only twenty minutes after the patient's death: La Motte, The Backwash of War (1916): 167-78.

75 Anon., My Beloved Poilus: 81.

76 Anon., My Beloved Poilus: 83.

77 Mortimer, A Green Tent in Flanders: 196-8.

78 La Motte, The Backwash of War (1916): 119-20.

79 Mortimer, A Green Tent in Flanders: 212.

80 La Motte, The Backwash of War (1916): 59.

81 Mortimer, A Green Tent in Flanders: 157.

82 Mortimer, A Green Tent in Flanders: 158.

83 Mortimer, A Green Tent in Flanders: 158.

84 Mortimer, A Green Tent in Flanders: 159.

85 Mortimer, A Green Tent in Flanders: 183.

86 Anon., My Beloved Poilus: 102. The two Canadian nurses being referred to here are members of the Canadian Unit of the FFNC. One, Helen McMurrich, spent several years working closely with Warner, and travelled home with her in 1919. See: Anon., 'French Flag Nursing Corps' BJN (29 April 1916): 378; Anon., 'French Flag Nursing Corps', BJN (27 May 1916): 458.

87 La Motte, The Backwash of War (1916): vi.

88 Borden, The Forbidden Zone: 168.

89 On the creation of heroic myths of warfare, see: Michael Paris, Warrior Nation: Images of War in British Popular Culture, 1850-2000 (London: Reaktion Books, 2000), passim; Graham Dawson, Soldier Heroes: British Adventure, Empire and the Imagining of Masculinities (London: Routledge, 1994), passim.

90 On Ellen La Motte's career, see: Higonnet, Nurses at the Front: ix-xv; Sugiyama, 'Ellen La Motte': 129-41. 